УДК 343.137.2

\author{
O. В. Сачко
}

\title{
РЕАЛІЗАЦІЯ ЄВРОПЕЙСЬКИХ СТАНДАРТІВ \\ У ВДОСКОНАЛЕННІ СПРОЩЕНИХ ТА ІНШИХ ОСОБЛИВИХ ФОРМ І ПОРЯДКІВ КРИМІНАЛЬНОГО ПРОВАДЖЕННЯ
}

Постановка проблеми. Курс України на євроінтеграцію потребує узгодження кримінально-процесуального права із загальновизнаними міжнародними стандартами правосуддя, що зумовлює необхідність аналізу проблем застосування таких нових інститутів кримінально-процесуального законодавства, як інститут заочного провадження, дізнання щодо кримінальних проступків, провадження на підставі угод.

Спроба реалізації приписів правових норм щодо особливостей провадження на підставі угод та в інших особливих формах, режимів і порядків спрощеного провадження показує наявність багатьох проблем, що лежать як у площині недосконалості законодавства, так і в реаліях діяльності слідчих, органів дізнання, прокуратури та суду.

Аналіз останніх наукових досліджень і публікацій, в яких започатковано розв'язання цієї проблеми, вказує на посилення уваги дослідників до європейських стандартів правосуддя $[4 ; 6 ; 8 ; 11 ; 12 ; 14 ; 20]$, проблем інституту провадження на підставі угод та застосування інших спрощених форм і особливих порядків кримінальних проваджень $[1 ; 2 ; 7 ; 9 ; 13$; $15 ; 19 ; 21-24]$, окремих аспектів заочного та дистанційного провадження [3; 10]. Зокрема, наявні публікації не вичерпують усю складну проблему, а швидше утворюють фундаментальну базу для ії подальшого дослідження.

Метою статті $€$ визначення ймовірних шляхів підвищення ефективності застосування особливих та спрощених форм і порядків кримінальних проваджень.

Виклад основного матеріалу дослідження. Під поняттям «міжнародні стандарти кримінального правосуддя» варто розуміти закріплені в міжнародно-правових актах відповідні принципи, вимоги, правила, норми, приписи тощо, а також правові позиції та прецедентну практику Європейського суду з прав людини, які стосуються кримінального судочинства, ухвалені з метою забезпечення належного правосуддя та мають зобов'язуючий характер для держав-учасниць Європейської конвенції з прав людини. 
До європейських стандартів правосуддя, перш за все, належать такі міжнародно-правові акти європейського значення: Конвенція про захист прав людини і основоположних свобод; Європейська конвенція з відшкодування шкоди жертвам насильницьких злочинів від 24 листопада 1983 р.; Європейська конвенція про запобігання тортурам та нелюдському або такому, що принижує гідність, поводженню чи покаранню 1987 р. та деякі інші рекомендації, резолюції та інші джерела нормативних актів.

Реалізація міжнародних стандартів у судовому провадженні відбувається через їх втілення у змісті правовідносин, що виникають між суб'єктами (учасниками) кримінального процесу. Оскільки міжнародні стандарти за своєю сутністю виступають нормами права, основними формами їх реалізації у судовому провадженні варто вважати застосування, використання, виконання та дотримання [8].

3 огляду на положення ст. 9 Конституції України про те, що чинні міжнародні договори, згода на обов'язковість яких надана Верховною Радою України, є частиною національного законодавства України, у процесі здійснення процесуальної діяльності міжнародні договори застосовуються, якщо вони не суперечать Конституції України.

Закон України «Про міжнародні договори України» від 22 грудня 1993 р. (ч. 1 ст. 1) визначає, що під міжнародними договорами варто розуміти договори, угоди, конвенції, пакти, протоколи, обмін листами чи нотами, інші форми і найменування міжнародних договорів, а ч. 1 ст. 19 цього Закону передбачає: «Чинні міжнародні договори України, згода на обов'язковість яких надана Верховною Радою України, є частиною національного законодавства і застосовується у порядку, передбаченому для норм національного законодавства».

Ратифікація Першого протоколу та протоколів № 2, 4, 7, 11 і 14 до Європейської Конвенції про захист прав людини та основних свобод відкрила змогу українським громадянам здійснювати їх захист із застосуванням юрисдикції Європейського суду з прав людини.

Законом України «Про виконання рішень та застосування практики Європейського суду з прав людини» від 23 лютого 2006 р. визначено: суди мають застосовувати під час розгляду справ практику Європейського суду 3 прав людини як джерело права (ст. 17); законодавчий орган держави (орган представництва) має здійснювати експертизу та перевірку чинних законів і підзаконних актів на відповідність Конвенції та практиці Європейського суду з прав людини (ст. 19).

Станом на 30 листопада 2014 р. в Європейському суді з прав людини загалом на розгляді перебувало 71600 справ, із них 13600 справ проти України (що становило 13,3\% від загальної кількості справ). В 2014 р. Україна «вийшла в лідери» і зайняла перше сумне місце в цій номінації. Наприкінці 2015 р. на розгляді в Європейському суді було 64850 справ, із них $13850(21,4 \%)$ - заяви проти держави України. У 2016 р. за рішеннями ЄСПЛ держава вже виплатила 612 млн грн. За минулий 2017 р. Європейський суд із прав людини отримав 18150 заяв від українців. Най- 
більше порушень (27) констатовано за ст. 5 «Право на свободу та особисту недоторканність» Конвенції про захист прав людини і основоположних свобод. Станом на 1 січня 2018 р. на розгляді ЄСПЛ перебувало приблизно 7100 скарг від громадян України, що є четвертим показником серед країн-членів Ради Європи: Туреччина (7 500), Росія (7 750) та Румунія (9 900). За результатами розгляду справ в ЄСПЛ Україна отримала 73 негативних ухвали. Варто зазначити, що, на перший погляд, зниження рівня порушень прав людини, в певних аспектах пов'язане із безпрецедентним рішенням «Бурмич та інші проти України», за яким ЄСПЛ викреслив зі свого реєстру понад 12 тисяч скарг на Україну про системне невиконання рішень національних судів, передавши їх розгляд у Комітет міністрів. У 2017 р. Україна виплатила за рішеннями ЄСПЛ майже 1,5 млрд грн.

Така сумна для України статистика в роботі поважної європейської правничої інституції показу на наявність багатьох поважних проблем забезпечення верховенства права в кримінальному судочинстві та реалізації в цій сфері європейських стандартів правосуддя.

Актуальними для реалізації в національному законодавстві залишаються рішення Європейського суду з прав людини у справах: «Загордній проти України» (рішення від 24 листопада 2011 р.); «Волохи проти України»; «Яременко проти України»; «Бортюк проти України»; «Єлоєв проти України»; «Шабельник проти України»; «Луценко проти України (рішення від 19 листопада 2012 р.), «Гглін проти України», «Чанєв проти України» (остаточне рішення від 9 січня 2015 р.) та інші.

Так, у справі «Гглін проти України» (Заява № 39908/05, рішення від 12 січня 2012 р.) Європейський суд із прав людини установив, що під час провадження у справі, а саме з 27 лютого 2004 р. до 4 серпня 2006 р., заявник тримався під вартою в Дніпропетровському слідчому ізоляторі № 3 i, як стверджував заявник, умови тримання в СІЗО були неналежними, зокрема через замалу площу камер, їх неналежне обладнання меблями, відсутність денного світла, неналежну вентиляцію тощо. Крім того, заявник стверджував, що, незважаючи на його численні клопотання про надання медичної допомоги, вона йому надана не була.

Європейський Суд із прав людини у справі «Шабельник проти України» констатував: заявник був допитаний як свідок, зізнався в процесі такого допиту у відсутності адвоката у вчиненому злочині, брав участь у відтворенні обстановки й обставин злочину як свідок і без захисника, де підтвердив свої зізнання, скаржився на те, що в основу обвинувачення покладені докази, здобуті незаконним шляхом. Суд установив, що засудження грунтується на показаннях, здобутих із порушенням права особи «на мовчання та права не свідчити проти самого себе» та з перешкодами з метою здійснення права на захист.

Значна кількість відступів від європейських стандартів правосуддя та порушень прав людини допускається у разі застосування спрощених процесуальних процедур.

Особливі форми та порядки проваджень, які викладені в КПК України як окремі постійно чинні інститути, умовно можна поділити на дві групи: 
1) спрощені форми кримінального провадження: а) провадження на підставі угод, б) здійснення спеціального (заочного) досудового розслідування (in absentia), в) провадження дізнання щодо кримінальних проступків тощо; 2) ускладнені процедури проваджень: особливості кримінальних проваджень відносно осіб, щодо яких передбачений статус недоторканності та інший підвищений ступінь захисту; провадження у справах про злочини та інші кримінальні правопорушення неповнолітніх тощо.

Однією з найбільш актуальних проблем $є$ формування процесуального інституту спрощеного кримінального провадження на підставі угод.

У Рекомендації Комітету Міністрів Ради Європи № R (81) 7 від 14 травня 1981 р. «Шодо шляхів полегшення доступу до правосуддя» (розділ «Спрощення», п. 3) підкреслено, що варто вжити заходи до полегшення або заохочення, де це можливо, примирення сторін або дружнього врегулювання суперечки до прийняття його до провадження або під час розгляду.

Рекомендація Комітету Міністрів Ради Європи № R (87) 18 від 17 вересня 1987 р. «Щодо спрощення кримінального правосуддя» так само визнає позасудове врегулювання засобом спрощення судочинства і зазначає у розділі II п. b «Позасудове врегулювання», що Законом мають передбачатися умови, які відповідні органи можуть поставити перед підозрюваним, а їх виконання робить остаточною відмову від права на судове переслідування для того, щоб забезпечити максимальне дотримання принципу рівності перед Законом.

Якщо угода про примирення підозрюваного з потерпілим є корисною формою судового компромісу, то застосування спрощеного провадження на підставі угоди про визнання винуватості спричинить багато ризиків судових помилок, які можуть проявитись у притягненні до відповідальності невинуватої особи.

Практика укладання угод у кримінальному провадженні неодноразово була предметом розгляду в Європейському суді з прав людини (справи «Ніколов проти Болгарії, «Бабар Ахмад та Інші проти Сполученого Королівства», Saunders v. the United Kingdom, judgment of 17 December 1996, Reports of Judgments and Decisions 1996-VI, у справi Sehmi v. the United Kingdom (dec.), No. 43470/98, 6 April 2000, у справі Armstrong v. the United Kingdom (dec.), no. 48521/99, 16 July 2002, у справі Merit v. Ukraine, No. 66561/01, judgment of 30 March 2004. Не заперечуючи можливості існування інститутів угод у кримінальному процесі, ЕСПЛ наголошує на необхідності дотримання умови - відповідність угоди фактичним обставинам справи.

Угода про визнання вини, передбачена ст.ст. 468-475 КПК України, суперечить конституційному принципу презумпції невинуватості. В ч. 3 ст. 349 КПК України визначено: «Суд має право, якщо проти цього не заперечують учасники судового провадження, визнати недоцільним дослідження доказів щодо тих обставин, які ніким не оспорюються. При цьому суд з'ясовує, чи правильно розуміють зазначені особи зміст цих обставин, чи немає сумнівів у добровільності їх позиції, а також роз'яснює 
їм, що у такому разі вони будуть позбавлені права оскаржити ці обставини в апеляційному порядку». Отже, якщо ж суд не досліджує доказів, а доказами є лише те, що суд безпосередньо сприймає, то які взагалі докази можуть існувати в такому кримінальному провадженні?

У Конвенції про захист прав людини та основних свобод (1950р.), яку Україна ратифікувала 17 липня 1997 р., визначено основні права і свободи людини, а виконуючи зобов'язання за міжнародним договором, варто враховувати тлумачення Європейського суду з прав людини. Це випливає зі ст. 32 Конвенції, згідно з якою юрисдикція Суду поширюється на всі питання, які стосуються тлумачення та застосування Конвенції і протоколів до неї. Прецедентна практика Європейського суду з прав людини стає важливим джерелом кримінально-процесуального права України.

ЄСПЛ удосконалює свої позиції в таких складних проблемах. Так, у 2018 р. у справі “Mirovni Inštitut v. Slovenia” (рішення 13.03.2018р.), ЕСПЛ установив, що судовий розгляд має гарантувати право на публічне слухання в розумінні $\S 1$ ст. 6 Конвенції, оскільки такий принцип $є$ певним засобом суспільного контролю, одним зі способів утвердження довіри до суду. Таким чином, розгляд справ у спрощеному провадженні без виклику сторін суперечить практиці ЕСПЛ. Відповідно, вироки, винесені без всебічного дослідження доказів у суді, можна без гарантованого права підсудного задавати питання свідкам, що свідчать проти нього, а також без участі сторони захисту в дослідженні інших доказів можна вважати незаконними.

Щодо обмеження права на оскарження вироку в разі укладення угоди про визнання винуватості є заперечення, викладені в ст. 14 Міжнародного пакту про громадянські і політичні права, де, зокрема, зазначається: «Кожен, кого засуджено за будь-який злочин, має право на те, щоб його засудження і вирок були переглянуті судовою інстанцією вищого порядку згідно із законом».

Ст. 17 КПК України приписує: «Ніхто не зобов'язаний доводити свою невинуватість у вчиненні кримінального правопорушення і має бути виправданим, якщо сторона обвинувачення не доведе винуватість особи поза розумним сумнівом». Сумніви будуть завжди без всебічного судового дослідження усіх доказів кримінальної справи. Зазначимо також, що суд відмовляє в затвердженні угоди, відповідно до ст. 474 КПК України, якщо «відсутні фактичні підстави для визнання винуватості».

Значні проблеми із забезпеченням верховенства права можуть з'явитись у разі застосування новітніх інститутів дізнання щодо кримінальних проступків. Наприклад, запроваджуваною в КПК України ст. 298-2 пропонується надати органу дізнання право затримувати уповноваженою службовою особою особу, яка підозрюється у вчиненні кримінального проступку, «у випадках, передбачених п.п. 1 і 2 ч. 1 ст. 208 цього Кодексу». При цьому «затримання особи, яка вчинила кримінальний проступок, здійснюється не більш як на три години з моменту фактичного затримання». Незважаючи на передбачений порівняно короткий термін затримання, закон допускає змогу без ухвали слідчого судді затримувати особу, підозрювану у вчинен- 
ні кримінального проступку, тоді як, згідно зі ст. 29 Конституції України, «у разі нагальної необхідності запобігти злочину чи його припинити уповноважені на те законом органи можуть застосувати тримання особи під вартою як тимчасовий запобіжний захід». Тобто Конституція України дає змогу застосовувати інститут затримання без ухвали слідчого судді лише щодо осіб, підозрюваних у вчиненні злочину, i не передбачає затримання особи за підозрою у вчиненні кримінального проступку.

Із поглибленням судово-правової реформи виникає дедалі більше проблем конкуренції правових норм, які потребують інтегративного аналізу і комплексного вирішення на основі європейських стандартів правосуддя.

Висновки. Більш широке запровадження в слідчу і судову практику інститутів особливих спрощених форм, порядків і режимів кримінальних проваджень потребує системного інтегративного аналізу усіх джерел правових норм, включаючи європейські стандарти правосуддя, зміцнення гарантій захисту прав і свобод учасників процесу, розроблення та запровадження з урахуванням принципу верховенства права більш досконалої процедури слідства і судового розгляду відповідних справ, реалізації правових позицій ЄСПЛ у сфері розвитку стандартів правосуддя.

Перспективи подальшого дослідження проблеми вбачаються в розробленні на основі європейських стандартів правосуддя концептуальної моделі окремої глави КПК України, присвяченої особливим формам кримінальних проваджень.

\section{Література}

1. Власова Г.П. Спрощення кримінального судочинства України: історія, теорія, практика: монографія. Ірпінь: Видавництво Національного університету ДПС України, 2014. 422 с.

2. Добровольська О.Г. Проблеми інституту кримінального провадження на підставі угод. Право і суспільство України. 2013. № 5. С. 150-154.

3. Дроздов O.M. Наукові підходи щодо перспектив перегляду у екстраординарних судових провадженнях окремих судових рішень, ухвалених у заочному кримінальному провадженні. Форум права. 2015. № 1. С. 92-103.

4. Дудаш Т.І. Практика Європейського Суду з прав людини: навч.-практ. посіб. К.: Алерта, 2013. 368 c.

5. Кампо В.М. Мирові судді та громадські мирові судді в Україні: проблеми та перспективи впровадження. К.: Ін-т громадян. сусп-ва: ТОВ «ІКЦ Леста», 2007. 40 с.

6. Комарова Т.В. Суд Європейського Союзу: розвиток судової системи та практики тлумачення права ЄС: монографія. Харків: Право, 2018. 528 с.

7. Корж В.П. Проблемы устранения юридических коллизий в отдельных положениях Уголовного процессуального кодекса Украины. Вісник Академії адвокатури України. 2014. том 11, число 1(29). С. 62-69.

8. Коровайко О.I. Міжнародні стандарти кримінального судочинства в судовому провадженні України : монографія. Х.: Панов, 2016. 492 с.

9. Нестор Н.В. Запровадження медіації в кримінальному процесі України: проблеми теорії та практики: монографія. К.: Алерта, 2018. 182 с.

10. Пашковський M.I. Дистанційне кримінальне правосуддя: міф чи реальність? Вісник Верховного Суду України. 2001. № 5. С. 36-40.

11. Права і свободи людини і громадянина в Україні (доктрина Європейського суду з прав людини і Конституційного Суду України): навчальний посібник / звернення до читачів Голови Конституційного Суду України (VII. 2010-VII. 2013 роки) Головіна А.С.; вст. слов о і заг. ред. проф. Мартиненка П.Ф., Кампа В.М. К., 2013. 376 с. 
12. Правові позиції Європейського суду з прав людини: аналітичний огляд / О.М. Дроздов, О.В. Дроздова; за заг. ред. О.М. Дроздова, М.С. Ковтун, В.І. Ковтуна. Харків: Видавничий будинок «Фактор», 2018. 624 с.

13. Прилуцький П.В. Угода про визнання винуватості в кримінальному провадженні : новела процесуального законодавства України. Бюлетень Міністерства юстиції України: Офіційне видання. 2013. № 4. С. 128-135.

14. Стандарты справедливого правосудия: международные и национальные практики / Воскобитова М.Р., Диков Г.В., Насонов С.А. и др.; под ред. Т.Г. Морщаковой. Москва: Мысль, 2012. 583 с.

15. Тертишник В. Компроміс у кримінальному процесі. Підприємництво, господарство і право. 2002. № 11. С. 107-112.

16. Тертишник B.M. Верховенство права та забезпечення встановлення істини в кримінальному процесі України: монографія. Дніпропетровськ: Дніпроп. держ. ун-т внутр. справ; Ліра ЛТД, 2009.

17. Тертишник В.М. Кримінальний процес України. Особлива частина: підручник. Академічне видання. Київ: Алерта, 2014. 420 с.

18. Тертишник В.M. Науково-практичний коментар Кримінального процесуального кодексу України. Вид. 15-те, доповн. і перероб. К.: Правова Єдність, 2018. 854 с.

19. Тюрін, Г.Є. Принципи участі прокурора у кримінальному провадженні на підставі угод. Науковий вісник Міжнародного гуманітарного університету. Серія Юриспруденція. 2014. № 9-1. С. 229-232.

20. Фулей T.I. Застосування практики Європейського суду з прав людини при здійсненні правосуддя: Науково-методичний посібник для суддів. 2-ге вид. випр., допов. К., 2015. 208 с.

21. Цимбал П., Діков І. Приватне обвинувачення як особливий порядок кримінального провадження: історико-правовий аспект. Вісник Національної академії прокуратури України. 2016. № 3(45). С. 109-114.

22. Чумак К. Звільнення від кримінальної відповідальності у зв'язку із примиренням винного 3 потерпілим vs. угода про примирення: проблеми розмежування. Науковий часопис Національної академії прокуратури України. 2016. № 2. Ч. 2. С. 135-141.

23. Шаранич С.С. Депутатський імунітет та кримінальна відповідальність: європейський досвід. Актуальні проблеми держави і права. 2014. № 73. С. 462-467.

24. Щерба В.М., Юхно О.О. Кримінальне провадження в суді присяжних: монографія / За загальною редакцією доктора юридичних наук, професора О.О. Юхна. Харків: Панов, 2018. 274 c.

\section{Ано о т ц і я}

Сачко О. В. Реалізація європейських стандартів у вдосконаленні спрощених та інших особливих форм і порядків кримінального провадження. - Стаття.

У статті аналізуються проблеми забезпечення верховенства та інших європейських стандартів права при застосуванні інституту кримінального провадження на підставі угод, здійсненні спеціального (заочного) досудового розслідування (in absentia), досудового розслідування у районі проведення антитерористичної операції, а також застосуванні інших особливих форм, режимів і порядків кримінальних проваджень.

Ключові слова: європейські стандарти, верховенство права, спеціальні форми провадження, спрощене судочинство.

\section{Анн о т а и я}

Сачко A. B. Реализация европейских стандартов для совершенствования упрощённых и других особых форм та порядков уголовного производства. - Статья.

В статье анализируются проблемы обеспечения верховенства права при использовании института уголовного производства на основании договора о признании вины, осуществлении специального (заочного) досудебного расследования (in absentia), досудебного рассле- 
Сачко О. В. Реалізація європейських стандартів у вдосконаленні спрощених та інших... 113

дования в районе проведения антитеррористической операции, а также применении иных особых форм, режимов и порядков уголовных производств.

Ключевые слова: европейские стандарты, верховенство права, особые формы уголовного производства, упрощенное производство.

\section{S u m m a r y}

Sachko $0 . V$. The implementation of European standards to make simplified and other special order forms and modes of criminal proceedings. - Article.

The article analyses the problem of ensuring the rule of law when using institute criminal proceedings on the basis of the Treaty, implementation of the special (absentee) pre-trial investigation (in absentia), pre-trial investigation in the area of anti-terrorism opp5eracii, as well as the application of other special forms, modes and orders in criminal proceedings.

Key words: European standards, rule of law, special forms of criminal proceedings, simplified production. 